\title{
Fiber-reinforced High-strength Concrete under Elevated Temperature-Effect of Fibers on Residual Properties
}

\author{
SOFREN LEO SUHAENDI and TAKASHI HORIGUCHI \\ Division of Built Environment, Hokkaido University \\ Sapporoshi Kitaku Kita 13 Nishi 8, 060-8628, Japan
}

\begin{abstract}
Addition of polypropylene fibers was known to be an effective way in mitigating the explosive spalling failure mechanism, which occasionally happened during heat exposure of high-strength concrete. This paper presents the experimental results on residual properties of fiber-reinforced high-strength concrete under elevated temperature. Some variables being focused on, concerning the effect of fiber on high-strength concrete residual properties, included fiber volume fraction $\left(V_{f}\right)$, fiber length $\left(l_{f}\right)$, and fiber material. Meanwhile, residual properties being observed included compressive strength $\left(f_{c}\right)$, splitting tensile strength $\left(f_{t}\right)$, modulus of elasticity $(E)$, and water permeability coefficient $(k)$. Results from the tests showed that residual properties of polypropylene fiberreinforced high-strength concrete was significantly reduced compared with steel fiberreinforced high-strength concrete, especially in the terms of permeability performance, even though polypropylene fiber was found to be more effective in mitigating explosive spalling.
\end{abstract}

KEYWORDS: high-strength concrete, fire performance, explosive spalling, fiberreinforced concrete, fiber volume fraction

\section{INTRODUCTION}

High-strength concrete (HSC) is commonly produced by lowering the water to cement ratio (w/c) of concrete mix proportion. Others include the addition and/or replacement of cement by mineral admixtures (fly ash, silica fume, and GGBFS) and the combination of those techniques mentioned. The hydration of these cementitious materials inside the concrete mixture will create matrix networks with extremely low void structure, enhancing its mechanical and permeability performance. With the soaring usage of HSC in many civil engineering projects, better understanding on the properties of this type of concrete has become an inevitable need.

Some deterioration mechanisms on concrete structure require the transportation of deleterious agents (i.e., chloride, sulfate, etc.) dissolved in water permeating through the concrete surface. Severity of the attack will depend on the rate and extent of these agents being transported inside the concrete. Meanwhile, the rate and extent of these harmful agents will depend on the permeability property of the concrete which is usually characterized by its pore structure. Hence, with better pore structure thus low permeability property, HSC is considered to be more durable compared with normal strength concrete (NSC). This statement is quite relevant whenever both type of concrete are exposed to normal temperature condition.

Experimental research in the past reported that HSC behaved differently under elevated temperature condition compared with NSC. A sudden catastrophic failure mechanism, usually termed as explosive spalling, was inconsistently observed when HSC was 
exposed to high temperature condition [1,2]. Regardless of the true failure mechanism, buildup of a significant pore pressure inside the hardened cement paste was believed to be one possible reason causing explosive spalling. Better packing density, smaller, and less interconnected pores inside HSC would prevent water vapor from escaping quickly during thermal exposure. Then, once the vapor pressure exceeded concrete tensile strength, it failed in an explosive manner [3]. Other possibility that caused explosive spalling might be related to thermal incompatibility between aggregate and hardened cement paste [4]. Some other factors that need to be assessed dealing with HSC under elevated temperature would include moisture content, heating rate, and loading.

In an effort to provide 'passages' for water vapor, some researchers introduced the addition of polypropylene fibers inside the concrete mix. With the melting of fibers at $160-170^{\circ} \mathrm{C}$, water vapor could escape through the passages, reducing the pore pressure thus alleviating explosive spalling [5,6]. However, as the consequence of deliberately generated additional pores, residual properties of the concrete surviving heat exposure would be significantly reduced [7]. Hence, it would be a great importance to investigate the deterioration of the surviving concrete as further necessary adjustment to the structure would depend on these residual properties.

\section{EXPERIMENTAL PROGRAM}

\section{Specimens}

Seven series of concrete mixture, as shown in Table 1, were cast using ordinary portland cement, river sand $(\mathrm{FM}=2.9$ ), and river gravel (maximum nominal size of $20 \mathrm{~mm}$ ) in this experimental study. All series had the same variables: $w / c$ of 0.3 , sand to aggregate ratio ( $\mathrm{s} / \mathrm{a}$ ) of $60 \%$, and water content of $170 \mathrm{~kg} / \mathrm{m}^{3}$. In order to obtain desired workability and air content of the fresh concrete, high-range water-reducing admixture (HRWA), airentraining admixture, and bubble cutter agent were added accordingly inside the concrete mixture. Each series was differentiated by the inclusion of fibers, which varied in $V_{f}, l_{f}$, and material. Table 2 shows the fiber properties used in this experimental study.

After curing under lime-saturated water for 28 days, some specimens were heated using computer-controlled electric furnace. Heating rate was set at $10^{\circ} \mathrm{C}$ per minute with peak temperature maintained at $200^{\circ} \mathrm{C}$ and $400^{\circ} \mathrm{C}$ for 2 hours. Reading of temperature inside electric furnace was carried out by means of one thermocouple attached to the side of the specimen. After letting the specimens to cool naturally to room temperature, heated specimens were tested along with the non-heated specimens. All specimens tested in the experimental study were $\phi 10 \times 20 \mathrm{~cm}$ cylindrical concrete specimens with no load applied to specimens undergone heat exposition.

Table 1. Mixture proportion.

\begin{tabular}{|c|c|c|c|c|c|c|c|c|c|c|}
\hline \multirow{2}{*}{ Series } & \multirow{2}{*}{ Code } & \multirow{2}{*}{$w / C$} & \multirow{2}{*}{$\begin{array}{l}S / a \\
(\%)\end{array}$} & \multicolumn{2}{|c|}{ Fiber volume (\%) } & \multirow{2}{*}{$\begin{array}{c}\text { HRWA }^{a} \\
(\% \times c)\end{array}$} & \multirow{2}{*}{$\begin{array}{l}\mathrm{AE}^{\mathrm{b}} \\
(\mathrm{A})\end{array}$} & \multirow{2}{*}{$\begin{array}{l}\mathrm{BC}^{\mathrm{c}} \\
(\mathrm{T})\end{array}$} & \multirow{2}{*}{$\begin{array}{l}\text { Slump flow } \\
\text { (mm) }\end{array}$} & \multirow{2}{*}{$\begin{array}{l}\text { Air } \\
(\%)\end{array}$} \\
\hline & & & & $\mathrm{pp}$ & steel & & & & & \\
\hline Plain & Plain & \multirow{7}{*}{0.3} & \multirow{7}{*}{60} & $\bar{\sim}$ & $\sim \sim$ & 1.3 & 7 & $\sim$ & \multirow{7}{*}{$400-600$} & \multirow{7}{*}{$5-7$} \\
\hline PFRC 6 - 0.25 & P6-0.25 & & & 0.25 & $\sim$ & 1.3 & 3 & 1 & & \\
\hline PFRC 6 - 0.5 & P6-0.5 & & & 0.5 & $\sim$ & 1.3 & 3 & 1 & & \\
\hline PFRC $30-0.25$ & P30-0.25 & & & 0.25 & $\sim$ & 1.7 & 3 & 2 & & \\
\hline PFRC $30-0.5$ & P30-0.5 & & & 0.5 & $\sim$ & 1.9 & 3 & 2 & & \\
\hline SFRC $30-0.25$ & S30-0.25 & & & $\sim$ & 0.25 & 1.3 & 3 & 1 & & \\
\hline $\begin{array}{l}\text { SFRC } 30-0.5 \\
\end{array}$ & S30-0.5 & & & $\sim$ & 0.5 & 1.3 & 3 & 1 & & \\
\hline
\end{tabular}

${ }^{a}$ High-range water-reducing admixture= Paric FP300U

${ }^{\mathrm{b}}$ Air entraining admixture= Flowric AE200, $1 \mathrm{~A}=0.004 \% \mathrm{x}$ cement (by weight)

${ }^{\mathrm{c}}$ Bubble cutter agent, $1 \mathrm{~T}=0.0002 \% \mathrm{x}$ cement (by weight) 
Table 2. Fiber properties.

\begin{tabular}{l|c|c|c|c|c|c}
\hline \multirow{2}{*}{ Fiber material } & $\begin{array}{c}\text { Length } \\
(\mathrm{mm})\end{array}$ & Shape & Denier & $\begin{array}{c}\text { Effective } \\
\text { diameter }(\mathrm{mm})\end{array}$ & $\begin{array}{c}\text { Aspect ratio } \\
(l / d)\end{array}$ & $\begin{array}{c}\text { Specific } \\
\text { gravity }\end{array}$ \\
\hline \hline Steel & 30 & Straight-hooked & - & 0.6 & 50 & 7.8 \\
\hline \multirow{2}{*}{ Polypropylene } & 6 & \multirow{2}{*}{ Fibrillated } & 20 & 0.06 & 100 & \multirow{2}{*}{0.9} \\
\cline { 2 - 4 } & 30 & & & 500 & \\
\hline
\end{tabular}

\section{Experimental Tests}

In the case of loading test, loading rate for compressive strength test and splitting tensile strength test was set at $2 \mathrm{kN} / \mathrm{s}$ and $0.2 \mathrm{kN} / \mathrm{s}$ respectively. Compressometer was attached on the concrete specimen during compressive strength test in order to calculate the modulus of elasticity of the specimen.

As for permeability test, specimen was fixed inside the permeability cell as shown in Fig. 1. After assuring that there would be no leakage from the interfacial boundaries, deaired water was filled into the cell. Then, pressure was applied to the specimen utilizing nitrogen gas. By this set up, assurance of uniform pressure distribution to the concrete specimen was achieved.

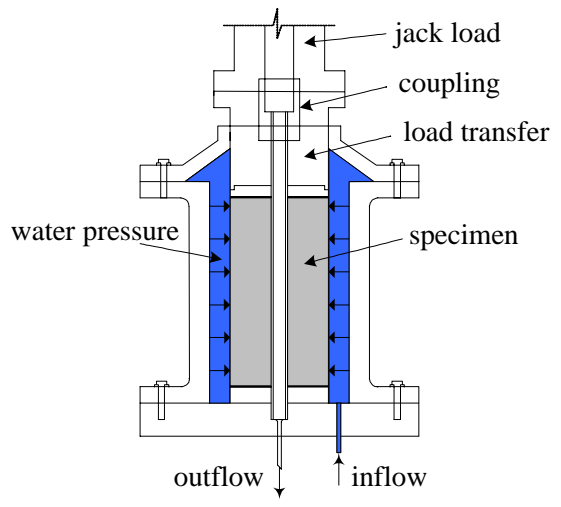

Fig. 1. Permeability cell.

Assuming water flow through the concrete specimen to be continuous and laminar, water permeability coefficient $(k)$ was calculated based on Darcy's formula. There were two methods, namely input and output method, involved in the test. Input method was applied to non-heated specimens while output method to heated specimens. The main difference between these two methods lies in the fact that water permeating concrete specimen came out only on the latter method.

Input method: $\quad k=\frac{d^{2}}{2 h t}$

where: $d=$ water penetration depth (m), $h=$ water head (m), and $t=$ time (s) 
Output method:

$$
k=\frac{\rho \ln \left(\frac{r_{o}}{r_{i}}\right)}{2 \pi H} \frac{Q}{P}
$$

where: $\rho=$ water density $\left(\mathrm{kgf} / \mathrm{m}^{3}\right), r_{o}=$ specimen radius $(\mathrm{m}), r_{i}=$ central hole radius $(\mathrm{m})$, $Q=$ water outflow $\left(\mathrm{m}^{3} / \mathrm{s}\right), H=$ specimen height $(\mathrm{m})$, and $P=$ water pressure $\left(\mathrm{kgf} / \mathrm{m}^{2}\right)$

\section{RESULTS AND DISCUSSION}

During heating of the specimens, explosive spalling was observed on the plain highstrength concrete within the temperature range of $350-400^{\circ} \mathrm{C}$ inside the electric furnace with the occurrence percentage of 25\%. From 8 specimens designated for compressive and splitting tensile strength test, 2 specimens spalled in explosive manner when they were supposed to be heated at $400^{\circ} \mathrm{C}$. Spalling happened when temperature inside electric furnace was raising to about $370^{\circ} \mathrm{C}$. While the reason causing this failure mechanism was unclear, the occurrence confirmed that explosive spalling might take place inconsistently on HSC under elevated temperature condition. Table 3 shows the summary of the performed test results in this experimental study.

Table 3. Experimental test results.

\begin{tabular}{|c|c|c|c|c|c|c|c|c|c|c|c|c|}
\hline \multirow{2}{*}{ Series } & \multicolumn{3}{|c|}{$f_{c}(\mathrm{MPa})$} & \multicolumn{3}{|c|}{$E(\mathrm{GPa})$} & \multicolumn{3}{|c|}{$f_{s p}(\mathrm{MPa})$} & \multicolumn{3}{|c|}{$k\left(\times 10^{-12} \mathrm{~m} / \mathrm{s}\right)$} \\
\hline & $20^{\circ} \mathrm{C}$ & $200^{\circ} \mathrm{C}$ & $400^{\circ} \mathrm{C}$ & $20^{\circ} \mathrm{C}$ & $200^{\circ} \mathrm{C}$ & $400^{\circ} \mathrm{C}$ & $20^{\circ} \mathrm{C}$ & $200^{\circ} \mathrm{C}$ & $400^{\circ} \mathrm{C}$ & $20^{\circ} \mathrm{C}$ & $200^{\circ} \mathrm{C}$ & $400^{\circ} \mathrm{C}$ \\
\hline Plain & 81.6 & 65.2 & 51.8 & 34.3 & 25.8 & 14.8 & 4.4 & 3.7 & 3.1 & 2.38 & 46.8 & 44 \\
\hline P6-0.25 & 60.8 & 54.1 & 35.6 & 32.4 & 27.7 & 13.8 & 4.1 & 3.5 & 2 & 3.84 & 175 & 884 \\
\hline P6-0.5 & 60 & 49.8 & 32.7 & 29.6 & 24.3 & 8.3 & 4.3 & 3 & 2 & 15.5 & 394 & 8130 \\
\hline P30-0.25 & 71.9 & 61.3 & 47.4 & 33.2 & 24.9 & 13.4 & 5.4 & 3.9 & 2.6 & 14 & 1660 & 33700 \\
\hline P30-0.5 & 59.4 & 50.7 & 30.9 & 32.4 & 20.9 & 8.0 & 4.7 & 3.3 & 2.3 & 17.9 & 6180 & 51500 \\
\hline S30-0.25 & 68 & 63.6 & 45.8 & 36.8 & 27.3 & 13.6 & 5.2 & 3.9 & 3.3 & 22.2 & 528 & 945 \\
\hline S30-0.5 & 75.1 & 66.1 & 49.8 & 41.7 & 30.6 & 13.3 & 5.4 & 4.7 & 3.7 & 5.16 & 115 & 728 \\
\hline
\end{tabular}

\section{Effect of Temperature on Residual Properties}

It is obvious that residual properties of all concrete specimens deteriorated with the increasing of peak temperature as shown in Fig. 2. With the dehydration of $\mathrm{CH}$ at temperature above $350^{\circ} \mathrm{C}$, significant deterioration occurred to concrete specimens heated at $400^{\circ} \mathrm{C}$. Table 4 shows the average reduction of concrete specimens’ properties after being exposed to the designated peak temperature.

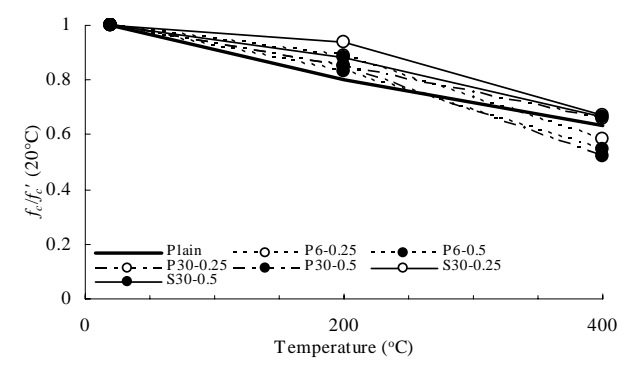

a) Compressive strength

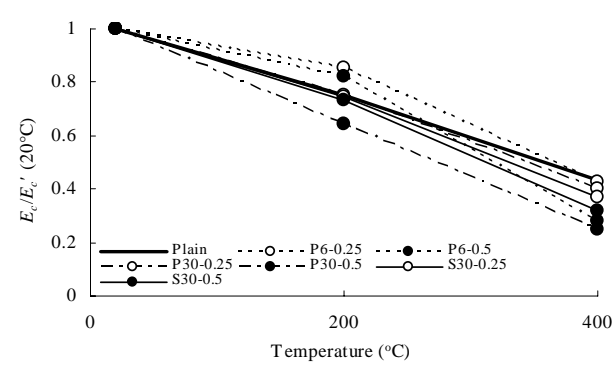

b) Modulus of elasticity 


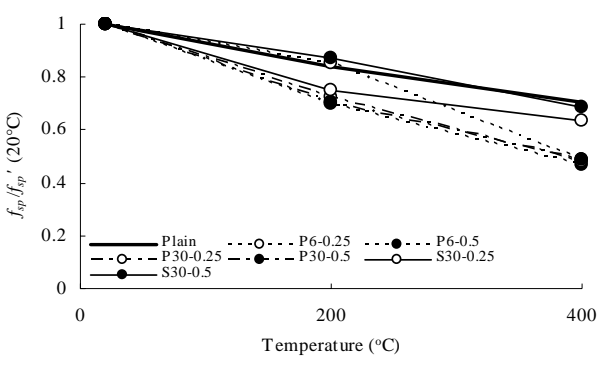

c) Splitting tensile strength

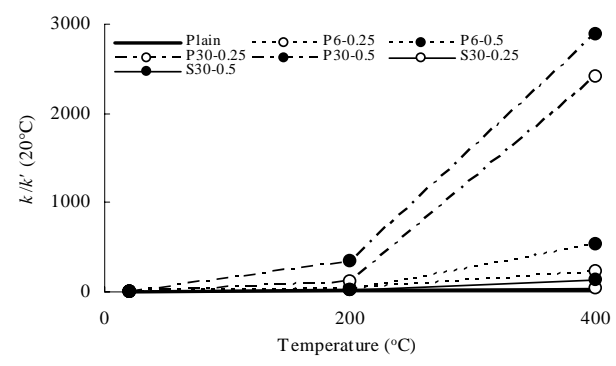

d) Water permeability coefficient

Fig. 2. Relative residual properties of fiber-reinforced high-strength concrete.

Table 4. Average reduction of heated concrete.

\begin{tabular}{l|c|c|c|c|c|c|c|c}
\hline \multirow{2}{*}{ Series } & \multicolumn{9}{c|}{ Average reduction } \\
\cline { 2 - 9 } & \multicolumn{2}{|c|}{$f_{c}$} & \multicolumn{2}{c|}{$E$} & \multicolumn{2}{c}{$f_{s p}$} & \multicolumn{2}{c}{$k$} \\
\cline { 2 - 9 } & $200^{\circ} \mathrm{C}$ & $400^{\circ} \mathrm{C}$ & $200^{\circ} \mathrm{C}$ & $400^{\circ} \mathrm{C}$ & $200^{\circ} \mathrm{C}$ & $400^{\circ} \mathrm{C}$ & $200^{\circ} \mathrm{C}$ & $400^{\circ} \mathrm{C}$ \\
\hline \hline Plain & 20 & 37 & 25 & 57 & 16 & 30 & -19 & -17 \\
\hline PFRC & 14 & 42 & 23 & 66 & 26 & 52 & -133 & -1509 \\
\hline SFRC & 9 & 33 & 26 & 66 & 19 & 34 & -22 & -91 \\
\hline
\end{tabular}

* all values are in \%, except for $k$, in times

Polypropylene fiber-reinforced concrete (PFRC) significantly lost its mechanical properties after suffering from heat exposure, especially at temperature of $400^{\circ} \mathrm{C}$, compared with steel fiber-reinforced concrete (SFRC). In terms of residual mechanical properties being investigated, modulus of elasticity was found to be the worst affected property, which was considered as a common phenomenon on concrete under elevated temperature, in all series.

For PFRC, the melting of polypropylene fibers at fusion point of $160-170^{\circ} \mathrm{C}$ degraded its permeability performance remarkably. The pores once mitigated explosive spalling failure mechanism would facilitate water penetration through the concrete. Increase in water permeability coefficient of 3 orders of magnitude might be observed on PFRC after heat exposure at $400^{\circ} \mathrm{C}$ while water permeability coefficient of SFRC might increase by 2 orders of magnitude after heat exposure at the same particular temperature.

\section{Effect of Fiber on Residual Properties}

Figure 3 shows the effect of fiber volume fraction on the residual properties of fiberreinforced high-strength concrete. More addition of fibers seemed to reduce the residual properties of both PFRC and SFRC. However, this trend was not observed on the splitting tensile strength property of SFRC. This might indicate that more addition of steel fibers were quite effective in bridging the cracks initiated during the splitting tensile strength test. For PFRC, more addition of polypropylene fibers would mean more pores produced inside the concrete matrix which would lead to more deterioration on its residual properties. 


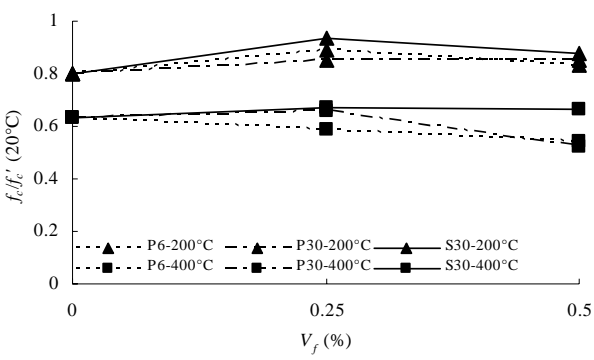

a) Compressive strength

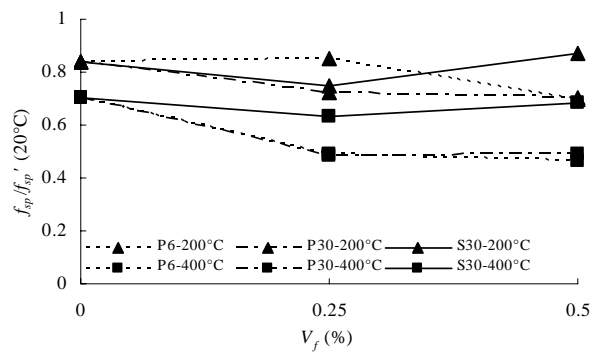

c) Splitting tensile strength

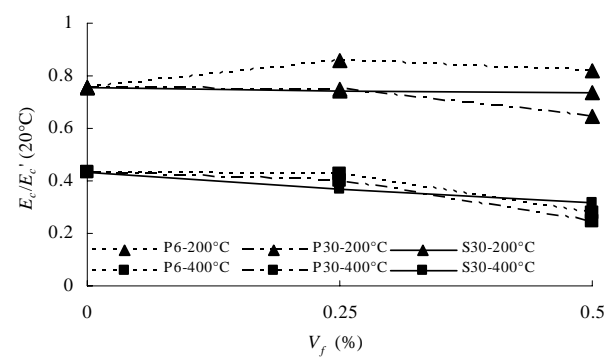

b) Modulus of elasticity

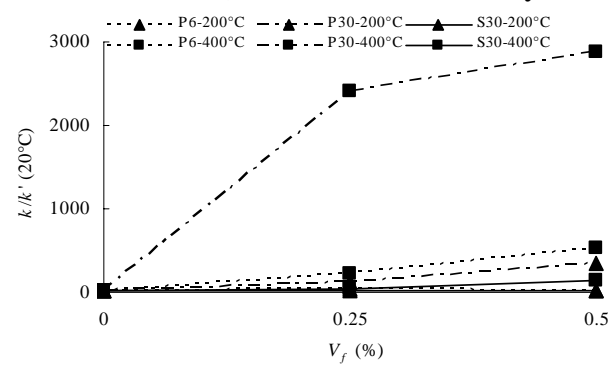

d) Water permeability coefficient

Fig. 3. Effect of fiber volume fraction on residual properties of fiber-reinforced high-strength concrete.

In this experimental study, effect of fiber length on the residual properties of fiberreinforced high-strength concrete applied only to PFRC, as shown in Fig. 4. In terms of residual mechanical properties, effect of polypropylene fiber length was not obviously noticed. On the contrary, effect of polypropylene fiber length was clearly observed on permeability performance of heated PFRC. Once the polypropylene fibers melted, longer fibers would leave more interconnected voids providing means for water to easily permeate the concrete thus increasing the water permeability coefficient.

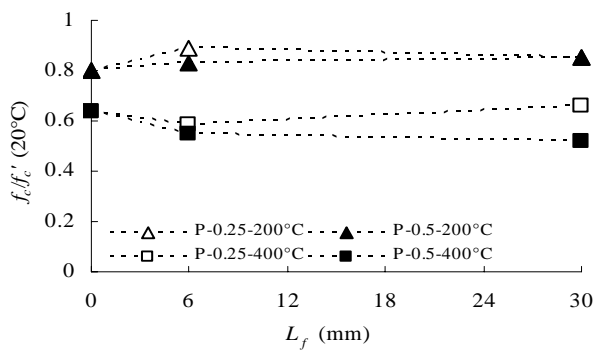

a) Compressive strength

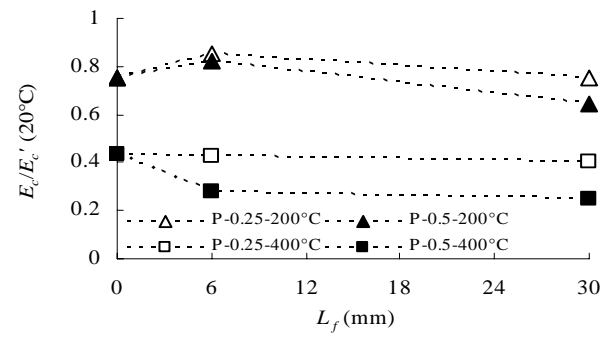

b) Modulus of elasticity 


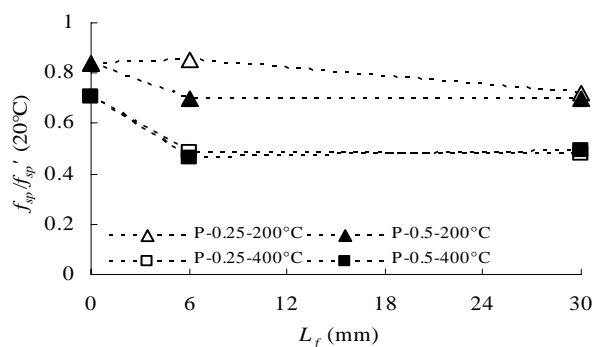

c) Splitting tensile strength

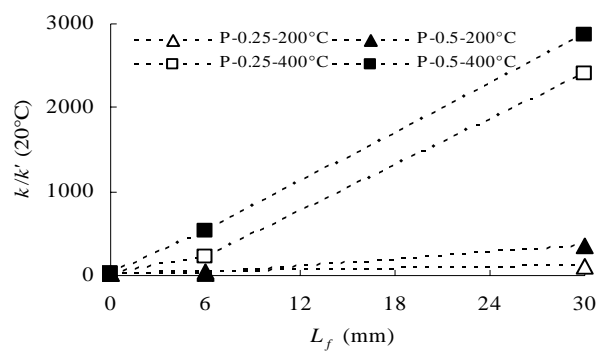

d) Water permeability coefficient

Fig. 4. Effect of fiber length on residual properties of polypropylene fiber-reinforced high-strength concrete.

\section{CONCLUSIONS}

1. Explosive spalling of plain high-strength concrete was inconsistently observed within the temperature range of $350-400^{\circ} \mathrm{C}$ inside the electric furnace. For specimens containing fibers, no explosive spalling was observed.

2. Polypropylene fiber-reinforced concrete tended to experience more reduction on its properties after heat exposure compared with steel fiber-reinforced concrete and plain concrete. In terms of mechanical properties, modulus of elasticity was found to be the worst affected property in all series.

3. The melting of polypropylene fibers inside the matrix of PFRC would result in deterioration of its permeability performance. Increase in water permeability coefficient of 3 orders of magnitude might be observed on PFRC after heat exposure at $400^{\circ} \mathrm{C}$.

4. In the case of concrete under elevated temperature condition, more inclusion of fibers would reduce the residual properties of both PFRC and SFRC. Nevertheless, this trend was not observed on the splitting tensile strength property of SFRC.

5. For PFRC under elevated temperature condition, effect of fiber length was clearly observed on its permeability performance. Longer fiber would tend to reduce the permeability performance as it would leave more interconnected voids facilitating water to permeate inside the concrete.

\section{REFERENCES}

[1] Phan, L.T. and Carino, N.J., "Fire Performance of High-strength Concrete: Research Needs," Proceedings, Advanced Technology in Structural Engineering, ASCE/SEI Structures Congress 2000, May 2000, Philadelphia.

[2] Flynn, D.R., "Response of High Performance Concrete to Fire Conditions: Review of Thermal Property Data and Measurement Techniques," NIST GCR 99-767, US, Mar. 1999, pp. 1-2.

[3] Kodur, V.K.R., "Fire Performance of High-Strength Concrete Structural Members," Institute for Research in Construction, Canada, Dec. 1999.

[4] Phan, L.T., "Fire Performance of High-Strength Concrete: A Report of the State-of-the-Art," NISTIR 5934, U.S. Department of Commerce, December 1996. 
[5] Bilodeau, A., Malhotra, V.M., and Hoff, G.C., "Hydrocarbon Fire Resistance of High-Strength Normal Weight and Light Weight Concrete Incorporating Polypropylene Fibers," International Symposium on High Performance and Reactive Powder Concretes, Sherbrooke, QC, 1998, pp. 271-296.

[6] Shuttleworth, P., "Fire Protection of Concrete Tunnel Linings," Proceedings of the Third International Conference on Tunnel Fires, Oct. 2001, Washington, DC, pp. 157-165.

[7] Bayasi, Z. and Al Dhaheri, M., "Effect of Exposure to Elevated Temperature on Polypropylene Fiber-Reinforced Concrete,” ACI Materials Journal, V. 99, No. 1, 2002, pp.22-26.

[8] Janotka, I. and Bágel, L., "Pore Structures, Permeabilities, and Compressive Strengths of Concrete at Temperatures up to $800^{\circ} \mathrm{C}$," ACI Materials Journal, V. 99, No. 2, 2002, pp. 196-200.

[9] Suhaendi, S.L., Horiguchi, T., and Saeki, N., "Permeability of Heated FiberReinforced High-Strength Concrete," Proceedings of the Japan Concrete Institute, V. 26, No. 1, Jul. 2004, Kochi, Japan, pp. 315-320.

[10] Ichise K., Nagao K., and Nakane, S., "Study on Mechanical Properties of HighStrength Concrete Subjected to High Temperatures Heating," Proceedings of the Japan Concrete Institute, V. 19, No. 2, 1997, Japan, pp. 535-540. 